\title{
Those pietistic missionaries: a time to reconsider?
}

W A Saayman

\section{ABSTRACT}

It is generally recognised that pietistic missionaries made an enormous contribution to Christian mission world-wide. The author analyses the contribution of Afrikaans-speaking pietist missionaries in South Africa, and their social involvement. He concludes that it was exactly their Pietist tradition which led them into meaningful socio-political involvement to change oppressive structures. This should, however, not be taken as a clean bill of health for pietism in general.

\section{INTRODUCTION}

Much has been written about missionaries and pietism. It is generally accepted that the modern Protestant mission movement (that is to say, Protestant missions since the seventeenth century) is unthinkable apart from the contribution of pietism, and especially that of Count von Zinzendorf and the Moravians. The doyen of mission historians, Stephen Neill, states categorically: "The history of missions supported by Churches on the European continent begins only with the emergence of the movement called pietism ${ }^{n}$. Christian mission in South Africa ${ }^{2}$ was part of this phenomenon, and although the first Moravian missionary was only allowed into the Cape Colony in 1737, eighty-five years after the founding of the colony, pietism played as crucial a role in the founding of an indigenous Christian community in Southern Africa as in other European "mission fields" 3 .

The recent emphasis on a contextual approach to missiology 4 as well as the momentous changes in the South African political economy, with its emphasis on reconstruction, may provide an important opportunity to reconsider the contribution of pietist missionaries to the growth and development of the South African Christian faith community. This is the (limited) goal I set for myself in this article. The earliest pietist missionaries and pietistically inclined Dutch Reformed clergy who had a strong influence on Christian mission in South Africa, were all of European origin or studied in Europe, specifically Hollands. It is therefore clearly necessary for me to start by paying some attention to the characteristics of European (especially German, English Puritan and 
Revivalist, and Dutch Second Reformation ${ }^{6}$ ) pietism relevant to my topic. I will attempt this in a limited way only, in so far as it is necessary as an introduction to my topic.

\section{THE EUROPEAN PIETISTIC BACKGROUND}

As I have just stated, this article is not meant to be a full-blown historical or doctrinal treatise on pietism as such, and I do not intend to analyse the movement closely. I will therefore sketch the relevant characteristics in very broad outline only.

Neill7 mentions the following general principles of pietism: the demand for personal conversion and holiness; close fellowship with other like-minded believers in the community of faith (often characterised as an ecclesiola in ecclesia); a strong responsibility for witness to a lost world; and a living expectation of the early return of Christ, which serves as evangelistic motivation. To these I would add a very high, often literalistic, view of Scripture as God's Word. These characteristics must always be evaluated against the general ecclesiastical background of Western European churches at the time. Scherer points out that immediately before the rise of pietism in seventeenth century Germany, the Lutheran church had "raised almost insuperable obstacles to the development of a positive missionary tradition" 8 . In this way the missio Dei had indeed become "domesticated within the ecclesiastical boundaries of Christendom". A "powerful movement of renewal, attended by the Spirit", was necessary to overcome this domesticated inertia. Such a movement was generated by pietism ${ }^{9}$.

The impulse for this movement can be found especially in Spener's conviction that "Christianity consists more of practice (praxis pietatis) than of theory" 10 . This point is emphasised also by Rosenkranz. According to him, early pietists differed from quietists exactly in so far as the pietists were motivated by a deep commitment to "action in God" 11 . This is clearly reflected in Ziegenbalg's covenant with a student friend:

We will seek nothing else in the world but the glory of God's name, the spread of God's kingdom, the propagation of divine truth, the salvation of our neighbor, the constant sanctification of our own souls, wherever we may be and whatever of cross-bearing and suffering it may occasion us 12 .

Another trait of pietism reflected here is its wide vision, keeping the whole world in view (in contrast to the national Protestant churches with their limited view which considered themselves responsible only for national 
territories and perhaps colonies. This view was fully in line with the then generally operative ecclesiastical rule of cuius regio, eius religio. Pietists desired to serve the whole world with God's message as they understood it. In the atmosphere of "domesticated inertia" reigning in the European Protestant churches at the time, one could therefore expect that Christian and moral activists would gravitate naturally to the pietist camp, especially also because pietism created such remarkable scope for lay involvement. In other words: pietism presented a useful outlet for the energies of people who wanted "to change the world" - arguably always one of the distinctive traits of Christian missionaries.

The strong pietist emphasis on the word of God led naturally to a strong desire that all people should be able to read God's Word. This gave birth to one of the strong pietist mission principles: that church and school should go together ${ }^{13}$. Pietist mission was therefore characterised by a strong effort to provide people in the "mission fields" with education ${ }^{14}$. At the same time, pietist missionaries who claimed to be "constrained by Jesus' love", could not stand indifferent to the obvious suffering caused by sickness, disease, malnutrition, etcetera. So, pietist missionaries also early on included health workers.

Providing education and health services not only provided an excellent outlet for the activist streak of some pietist missionaries, it also brought them very close to the people among whom they served. Another characteristic of early pietism stood them in good stead here. As Rosenkranz indicates, their mission involvement was not dominated by any specific theory. They developed the norms regulating their actions on the basis of their understanding of the Bible and their practical experience ${ }^{15}$. This provided openness to improvisation, and a willingness to make changes as they went along. The spreading of the gospel remained the main driving force, and if the provision of schools and hospitals were necessary to accomplish that, then that is what they provided. At least in early pietism then, social involvement was not foreign to Christian praxis ${ }^{16}$. Indeed, in Reilly's words, "Loving service has marked the life styles of missionaries over the centuries" ${ }^{n}$.

\section{PIETIST MISSIONARIES IN SOUTH AFRICA}

German pietists, English revivalists, and protagonists of the Dutch Second Reformation, strongly influenced the developing Christian piety in Southern Africa ${ }^{18}$. European missionaries, influenced by the trends just mentioned, brought to this region the typical religious traits which 
characterised the pietist movement. It did not consist of a simple transplanting, though. The new context into which the missionaries moved, influenced the shape and form of pietism in Southern Africa. Christian mission in South Africa was decisively entangled with the colonial project19. And the imposition of the western colonial system was, according to Neill, part and parcel of the intoxicating discovery by western Europe of its own power in relation to the rest of the world20. One important dimension of this power relationship was the extreme disparity between Europe and (what would later be called) the Third World. This disparity in power and (what the missionaries considered to be) standards of civilisation (especially literacy, clothing, housing, armaments and a monetary economy) strengthened the missionaries' conviction of the superiority of all things European. This was the cause for the near identification between christianisation and (white) civilisation which developed in colonial mission endeavours. This extended to their views of African religion. It comes as no surprise, therefore, to read that many missionaries "assumed that Black Africans had no religion, no complex, satisfying views of the world, of human destiny and of supernatural powers" 21 . In such a context, one can understand the ease with which the superiority of the Christian religion and western civilisation was posited by all missionaries, pietists included.

Only western man (sic) was man in the full sense of the word; he was wise and good, and members of other races, in so far as they became westernized, might share in this wisdom and goodness. But western man was the leader, and would remain so for a very long rime, perhaps for ever22.

Combined with the assuredness of pietist faith convictions, this conviction about the obvious superiority of all things European, led to the conviction that "missionaries knew best", that Africans were little children in need of protection against the evils and dangers of the modern world23. Indeed, in some missionaries this was translated into an arrogant superiority complex.

Yet the burning evangelistic zeal, and compassion for the sick, the needy and the outcasts, which characterised pietistic missionary motivation in Europe, kept at least some pietistic missionaries close to "their" people, in spite of their sense of superiority. In this regard the development of distinct groups of mission enthusiasts among (white) Dutch Reformed clergy and members which Durand indicates 24 can fruitfully be employed to characterise all pietistic mission enthusiasts in South Africa. Durand identifies such a group as the spiritual heirs to Van Lier and Vos [and subsequently of Andrew Murray - WS], in other words especially of the 
pietist tradition as it was embodied in the Dutch Second Reformation. These Christians, he maintains, felt uncomfortably convinced that "it was impossible to concern oneself with the spiritual needs of the black people without coming across and doing something about their very real earthly needs" 25 .

Yet the people thus described, formed only one group among pietist missionaries. There were also significant numbers of pietist missionaries in South Africa who believed that their only responsibility was a spiritual one. They could draw on the later tradition in the Moravians which held that, where the execution of the spiritual mission had become impossible because of socio-political impediments, it was better that missionaries withdraw rather than become involved in "worldly" matters. The attitudes of this group are perhaps best reflected in the mission convictions of a person they would undoubtedly have recognised as leader: the spiritual giant, Andrew Murray (jr).

Even while still a student in the Netherlands in the 1840s, he became member of a revivalistic student movement, Sechor dabar. Members of this group consciously "tended to insulate themselves from secular and liberal influences at the Dutch universities"26. Back in his homeland (South Africa) he played an important role in the life and work of the Dutch Reformed Church, especially through his leading role in a series of interchurch conferences and revival movements during his ministry in Cape Town and Wellington during the 1860 s and 1870 s. He had a very wide audience, and was one of the first South African born pietists to reflect systematically on mission. The fruit of this labour was published in 1902 as Die sleutel tot die sendingvraagstuk (The key to the missionary problem).

For Murray, as for the pietist pioneer Von Zinzendorf, the leading ideal and motivation for Christian mission was "winning souls for the Lamb"27. This led logically to his conviction that mission was evangelisation (understood as "winning souls". For missionaries to win these lost souls for the Lamb, the Holy Spirit would provide the power in answer to fervent prayer ${ }^{28:}$

as much as we need to pray for the power of the Holy Spirit upon missionaries and their work, we need to pray for the leaders of mission work, and for the churches which support them, that all devising of means and methods, that all appeals for men and money, that all meetings for awakening interest or uniting prayer, may be in true dependence on the power of the Holy Spirit29.

The Murray evangelical and pietist tradition thus revealed the same general characteristics as pietists everywhere. The immediate context of great need 
and misery characterising the lives of black people around them, however, brought them into daily contact with earthly needs which clamoured for more direct social involvement. Eventually, says Durand ${ }^{30}$, this gave rise to "a sort of schizophrenic attitude" patterned on the overriding racist divisions of South African society. Apart from admirable involvement in providing black education, the church's missionary calling "was seen as spiritual with very little emphasis on the social side" ${ }^{m 1}$. Such an approach, often supposed to be politically "neutral", is in fact intensely political in nature ${ }^{32}$. This is so because "there is no pure ecclesiastical neutrality, just as there is no apolitical theology; there are only those who are conscious of their political assumptions and consequences and those who are not ${ }^{n 3}$.

At face value we have little promise here for an eventual worldshattering protest against the [racist] course of Afrikaner theology and history - and of course the results were meagre. But still they were there... There must therefore have been some hidden forces in this tradition that made dissent possible. In my opinion we have to look for these forces in the theologically much maligned pietism and the equally maligned idea of the Afrikaner's missionary calling ${ }^{34}$. It is to this topic that I now turn my attention.

\section{SOUTH AFRICAN PIETISM: A TIME TO RECONSIDER?}

As one's consideration of the rise of pietism has to take serious account of the reigning climate in the established European churches and society of the day, so also must any reconsideration of South African pietism take into account the ecclesiastical and political climate in South Africa, especially in the latter part of the nineteenth and the first half of the twentieth century. It was especially during this period that racism became institutionalised in South African society. Racism had always been an accepted, though often undefined, ingredient of the colonial project for various reasons. The discovery of diamonds (1867) and gold (1886) with the accompanying urbanisation and industrialisation of South Africa greatly accelerated and intensified the legal institutionalisation of racism, however ${ }^{35}$.

The development of a comprehensive philosophy to justify this institutionalisation of racism was strongly influenced by the rise of neoFichtean romantic nationalism in white (especially Afrikaner) South African thinking since the $1930 \mathrm{~s}^{36}$. Previously the tendency to an identification between people ("volk") and church and the subsequent creation of a national church ("volkskerk") had been held in check by the 
reigning evangelical-pietist and Kuyperian-Calvinist traditions in Afrikanerdom ${ }^{37}$. These inhibiting influences fell away, however, as NeoFichtean romantic nationalism took rapid root in especially Afrikaner society as a result of its propagation by leading young Afrikaners who had studied in Germany in the early 1930s. This resulted, in Bosch's words ${ }^{38}$, in a "religiously undergirded ethnic chauvinism" among white South Africans - Afrikaners in particular - characterised by Christian nationalism and a near total identification of church and nation. Socio-economic and political factors further contributed to this process ${ }^{39}$. It was within this context that the ambivalent tradition of South African pietism provided room for voices of dissent - all of them from the evangelical-pietist tradition ${ }^{40}$.

The names generally mentioned in this connection are well known: B B Keet and B J Marais; both professors of theology at Dutch Reformed theological faculties, who initiated the criticism in the 1940s and 1950s, and best known of all, C F B Naudé with his fearless criticism since the $1960 \mathrm{~s}^{41}$. All observers note that these men came from the Murrayevangelical wing of the Afrikaans churches, not from the KuyperianNeocalvinist wing. Although a few swallows do not necessarily make a summer, this reality nevertheless calls for serious consideration of the role of pietism in South Africa. Can one establish that what we are faced with here is indeed ascribable to some dimension of the South African pietist tradition itself?

I believe that it was indeed the pietist heritage in its South African incarnation which inspired this opposition. I referred above to the fact that the pietist concern for "their" people and their eternal salvation in some instances brought pietistically inclined missionaries and ministers uncomfortably close to the realities of everyday life in black South Africa. This is not an unimportant reality, for apartheid South Africa was carefully designed to create (at least) two separate "worlds" in one country: a privileged white world, and an exploited and oppressed black world. The white world was carefully protected, and all information emanating from the black world was carefully screened before it was allowed to enter the white world. In this way the myth could be perpetuated that "black South Africans are happy", and that any disturbances were the result of "foreign instigation". The existence of this myth was crucial for the maintenance of a sense of Christian benevolence in the minds of white South Africans.

It was in this context that the pietist desire to "win souls for the Lamb" brought about a real encounter of some white Christian missionaries (both lay and ordained) with the black world of disenfranchisement 
in all domains of life. In this way pietism created the possiblity of growth in human understanding (or humanisation) - a crucial condition for change in racist South Africa. The racially based South African "way of life", inherited from the (British) colonialist past, and which culminated in apartheid, rested firmly on a depersonalisation of people. All South Africans, but especially the ruling whites, were indoctrinated to see other South Africans as impersonal "blocs", "coloureds", "whites", "Africans", etcetera. Pietism, however, with its strong interest in personal salvation, militated against this depersonalising tendency. If one is "to win souls for the Lamb", one obviously cannot think primarily in terms of impersonal groups of people. Of necessity one becomes involved in very personal, individual aspects of their lives ${ }^{42}$. And in South Africa such an evangelistic ministry among black people meant getting face to face with the horrors (nowadays the legacy) of apartheid: migrant labour, single sex hostels, Group Areas Act, squatter camps, etcetera. But it was not only the practicalities of missionary evangelism at work here. Pietists' high regard for Scripture as God's Word also played a role, especially insofar as they rebelled against the Scriptural justification of apartheid as God's will for South Africa in Kuyperian-neocalvinism. Writing about Keet and Marais (and one might as well add Naudé and Van der Merwe's names), Durand states that it was exactly their "evangelical-pietist background" which "rebelled against identifying a social and political policy with biblical principles" ${ }^{43}$. In this way the pietist approach itself, in its embodiment in people engaged in mission within the South African context, paradoxically prepared the ground for socio-political involvement.

This paradoxical effect of pietism becomes even clearer when one views it in contrast to the effects of the other dominant theological influence shaping Afrikaner lives at the time, namely Kuyperianneocalvinism. According to Durand44, "Kuyperian cosmology was combined with orthodox Reformed Christology in such a way that any effort to subject theology to a Christological criticism was defused right from the start". And as Afrikaner Christian Nationalism developed apace during the 1940s and 1950s, with nearly unquestioned identification between church and people ("volk")45, it was more than anything else a christological corrective which was needed. As I have already indicated, this corrective developed in some adherents of the Murray-evangelical wing, for theological as well as contextual reasons. 


\section{CONCLUSION}

The question mark in the title of my article is not accidental. My intention with this article was certainly not to provide pietism and pietist missionaries with an unconditional "clean bill of health" ${ }^{46}$. My intention was much rather to motivate an ongoing process of reconsideration. As I have indicated above, pietism in South Africa was (and is) not a monolithic theological system. There are variations of pietism and pietist missionaries. One important reason why I consider such a process of reconsideration a necessity is provided by the nature of the church in Africa. Especially the Protestant wing of the African church is by and large an evangelical church. This evangelicalism is largely the result of the work of pietist missionaries. Whilst not pronouncing the evangelical piety and ethos above reproach in every respect, one certainly cannot condemn it out of hand as irrelevant, quietistic and/or simple false consciousness either. There is undoubtedly a link between (dimensions of) pietism and fundamentalism ${ }^{47}$. My argument in this article is that the full story of pietistic missionaries in South Africa indicates that pietism need not be equated with fundamentalism. There are other options which may develop in a specific context, leading to an engaged, sincere and acceptable Christian piety and ethos. Various dimensions of pietistically inspired mission enthusiasm came together in the South African context: the concern for personal salvation, in a society characterised by the devastations of racism, led to an engagement with both personal and structural aspects of racism. The idealism to "change the world", nurtured by pietist faith convictions, gave rise to social action which decisively influenced the South African community. At a time when we South Africans will need all possible resources to reconstruct, develop and reconciliate, the pietist heritage may indeed provide powerful and fruitful tools for this gigantic task.

\section{NOTES:}

1 S Neill, A history of Christian missions, London 1964, 227.

2 I will deal in this article mainly with white missionaries in South Africa, and mainly with Afrikaans-speaking ones at that. I do this because of the important socio-political role of Afrikaans-speaking churches in the formulation and justification of apartheid, and also because it is the tradition 1 know best. Furthermore 1 can build on the debate initiated in 3 excellent articles by D J Bosch, "The roots and fruits of Afrikaner civil religion", in: J W Hofmeyr \& W $S$ Vorster (eds), New faces of Africa. Essays in honour of Ben Marais, Pretoria 1984; D J Bosch, "The fragmentation of Afrikanerdom and the Afrikaner 
churches", in: C Villa-Vicencio \& J De Gruchy (eds), Resistance and hope, South African essanis in honour of Bejers Naude, Cape Town 1985 and J Durand, "Afrikaner piety and dissent", in: C Villa-Vicencio \& J De Gruchy, Resistance and hope, Cape Town 1985. For some reason (perhaps the rapid unfolding of events in the mid-eighties, with continuous states of emergency, perhaps the predominant role of the Kairos Document in setting the agenda for the theological debate since 1985) this important debate was not taken further at the time. I am furthermore concentrating mostly on the peculiar characteristics of pietism which influenced and were influenced by the South African context, well aware of the fact that pietism in South Africa was obviously part of a world-wide phenomenon.

3 J du Plessis, A history of Christian missions in South Africa, London 1911, 6169.

4 W A Saayman, "Christian mission history in South Africa. Rethinking the concept", Missionalia 23/2 (1995).

5 G Schmidt the Moravian, who arrived at the Cape in 1737, was the first missionary representing a mission society allowed to work in the colony. The Dutch Reformed clergymen generally credited with a mission revival in the early Dutch Reformed Church were $H \mathrm{R}$ van Lier (who started his ministry at the Cape in 1786), and M C Vos (who started his ministry in 1794).

6 The Dutch Second Reformation is perhaps not as well known as its pietist counterparts in Germany and England. It nevertheless had an important influence on the (Dutch) Cape colony towards the end of the eighteenth century (See D J Bosch, op cit, 1984, 25).

$7 \quad$ Neill, op cit, 228.

8 J A Scherer, Gospel, church and kingdom. Comparative studies in world mission theology, Minneapolis 1987, 70.

9 It is necessary to state, though, that one should not consider this enthusiastic activism in a one-sidedly positive light. The desire to break out of the domesticated inertia of the established churches gave rise to an impatience with all things theological, also theological training. Pietist missionaries were therefore often deficient in academic training; indeed, one can characterise their attitude as an anti-intellectual one. This sometimes translated into an attitude of: "There is no time to consider ("academic") questions such as the structures of the church, the role of culture, etc.; souls are perishing every day, and our only responsibility is to save them". It is understandable that such an attitude could give rise to threatening theological weaknesses.

10 Scherer, op cit, 71. 
11 G Rosenkranz, Die Christliche Mission. Geschichte und Theologie, München $1977,164$.

12 Quoted in M C Reilly, Spirituality for mission, Maryknoll 1978, 85.

13 Neill, op cit, 229.

14 The Danish mission in Tranquebar (Siegenbalg and Plutschau), and William Carey's mission in Bengal are instances which illustrate this point.

15 Rosenkranz, op cit, 176.

16 A König, “Evangelical theology”, unpublished paper, 1995.

17 Reilly, op cit, 122.

18 C Landman, The piery of Afrikaans uomen, Pretoria 1994, 9-13; Bosch, op cit, 25-26.

19 W A Saayman, Christion mission in South Africa: political and ecumenical, Pretoria 1991; W A Saayman, "Christian mission in South Africa: a historical overview”, International Review of Mission, LXXX111/328 (1994).

20 Neill, op cit, 244-250.

21 R Gray, Black Christians and white missionaries, New Haven 1990, 2.

22 Neill, op cit, 259.

23 This situation also strengthened the already strong emphasis in pietism on schooling and education.

24 Durand, op cit, 43-44. Durand distinguishes three groups in what he terms "the pietist and missionary tradition" or "the [Andrew] Murray evangelical and pietist tradition ${ }^{-}$within the white DRC. These were: a small, more pietistic and revivalistic group; a bigger group which was less revivalistic but nevertheless evangelistic; and a group which cut across the first two groups. These three groups, which he distinguishes from a neo-Calvinist Kuyperian group, kept the flame of missionary enthusiasm burning in the DRC. Please note that 1 differentiate between what is generally termed (mainstream) Calvinism, and its South African cousin, Kuyperian-neocalvinism. For a more extensive discussion of the meaning of this distinction, see Durand, op cit, 39-41, and Bosch, op cit, 1984, 26-29.

25 Durand, op cit, 44.

26 J Butler et al, Democraric liberalism in South Africa: its history and prospect, Cape Town 1987, 50. 
27 A Murray, The key to the missionary problem, For Washington 1979[1902], 44.

28 One can indeed argue that for Murray, Christian piety and devotion existed exclusively in fervent prayer - that indeed he had "prayerised" the Gospel. See Murray, op cit, 49,56-57.

29 Murray, op cit, 73-74.

30 Durand, op cit, 45.

31 Indeed, for Andrew Murray the Christian missionary task was to such an extent a personal, private responsibility, that he did not even raise the possibility of the so-called "ancillary services" of schools, hospitals, etcetera, in: The key to the missionary problem - cf Saayman, op cit, 1991, 48.

32 Bosch, op cit, 1984, 26 is right, therefore, in his conclusion that "pietism became a negative preparation for Afrikaner civil religion" and its heretical cousin, the theological justification of apartheid. This happened because pietism, in failing to come to grips with its political dimension, created a vacuum which "willy-nilly gave carie blanche to other forces to take over the nation's public life". I would argue that the obsession with "the communist danger" in church and state of the $1960 \mathrm{~s}-1980$ s may have flourished precisely as a result of the political vacuum at the heart of pietism.

33 Sölle, in: Saayman, op cit 1991, 51.

34 Durand, op cit, 45.

35 I describe this process more fully in a manuscript to be published in the first half of 1996 by Unisa Press: $A$ man with a shadow. The life and rimes of Prof $Z$ $K$ Matthews. A missiological interpretation in context. More extensive references to literature dealing with this phenomenon can be found there.

36 Bosch, op cit, 1984,32; op cit, 1985,61,66.

37 For a more extensive discussion of this dimension, see Bosch, op cit, 1984, 2932.

38 Bosch, op cit, 1984, 29-32.

39 Bosch, op cit, 1984, 30-32.

$40 \quad$ Bosch, op cir, 1985, 68.

41 Durand, op cit, 45-49; Bosch, op cit, 1985, 68-71; Saayman, op cit 1991, 55. Both Bosch, op cit, 1985, 69-71 and Durand op cit, 47-48 point to the Cottesloe 
Consultation as an important turning point in Naudé's opposition to Afrikanerdom. The Cottesloe Consultation took place in December 1960, and was the direct result of the Sharpeville massacre of 21 March 1960 (cf Saayman, op cit 1991, 73-80 for a fuller discussion of Cottesloe). I agree with them on the importance of this event, but wish to draw attention to a point which they do not mention. It is fairly general knowledge (as they also indicate) that all the DRC delegates to Cottesloe eventually recanted the views they had endorsed at the Consultation which were critical of the National Party and its apartheid system, except for Beyers Naudé. But there was another DRC delegate who stood firm in his convictions and never recanted: Prof Willie van der Merwe, at the time professor of missiology at the DRC faculty at Stellenbosch, and another representative of the Murray-evangelical wing of the church.

42 See Saayman, op cit, 1985, 56-57. The way in which this tendency operated in the lives of female missionaries is spelled out very clearly by Dana Robert in an excellent article on pioneer Afrikaans women missionaries. See Robert, "Mount Holyoake women and the Dutch Reformed Missionary Movement", Missionalia, 21/2 (1993).

43 Durand, op cit, 49.

44 Durand, op cit, 40.

$45 \quad$ Bosch, op cit, 1984, 26-32.

46 I would like to refer readers to Landman's analysis (Landman, op cit), which is decidedly more negative in tone than mine. Her book therefore should be considered as complementary reading to this article.

47 König, op cit, 